\title{
MENINGKATKAN HASIL BELAJAR FISIKA SISWA MELALUI PEMBERIAN SOAL TES BERGAMBAR PADA SISWA SMA
}

\author{
Haratua Tiur Maria.S \\ Universitas Tanjungpura. Pontianak
}

\begin{abstract}
This research is aimed to investigate the influence of implementing physic's test questions with picture to senior high school students for the increasing of physic students' learning outcome. Research is done in four different schools from different regencies in west Borneo by using data collection tools in form of analytical test to the students grade XI. The research is done by comparing the students' test result who has given the analytical test (verbal representation) and analytical test with picture (verbal representation and picture). Research outcome shows that most of the student learning outcome who has given the test question with picture is higher (11.57) rather than student learning outcome who has given the test question without picture (9.89) .
\end{abstract}

Kata kunci: Hasil belajar, Fisika, Tes bergambar.

Mencerdaskan kehidupan bangsa merupakan salah satu cita-cita pemerintah yang tertuang dalam pembukaan Undang-Undang Dasar (UUD) negara Republik Indonesia. Hal ini membawa konsekuensi bahwa pemerintah bertanggung jawab pada proses pendidikan nasional sebagai upaya untuk mewujudkan masyarakat Indonesia yang cerdas dan mampu bersaing dalam era globalisasi sekarang ini. Bahkan lebih khusus dalam Undang-Undang No. 20 tahun 2003 tentang sistem pendidikan disebutkan bahwa : "Pendidikan nasional bertujuan mengembangkan potensi peserta didik agar menjadi manusia yang beriman dan bertaqwa terhadap Tuhan Yang Maha Esa, berakhlak mulia, sehat, berilmu, cakap, kreatif, mandiri dan menjadi warga negara yang demokratis serta bertanggung jawab dalam rangka mencerdaskan kehidupan bangsa."
Untuk dapat mencapai tujuan pendidikan nasional, pemerintah menetapkan adanya delapan (8) standar nasional dalam penyelenggaraan pendidikan yang diharapkan dapat menjadi acuan agar dapat meningkatkan mutu pendidikan di Indonesia. Diantara delapan standar tersebut terdapat standar tentang Standar Kompetensi Lulusan (SKL), standar proses dan standar penilaian. Ketiga standar ini diharapkan dapat menjadi acuan guru dalam merencanakan dan melaksanakan pembelajaran serta melakukan penilaian proses pembelajaran di sekolah.

Namun dalam kenyatannya, rendahnya kualitas hasil dan proses pembelajaran masih merupakan salah satu masalah yang dihadapi dunia pendidikan di Indonesia. Hal ini berdampak pada belum meningkatnya mutu pendidikan secara signifikan. 
Berbagai upaya telah dilakukan pemerintah untuk meningkatkan mutu pendidikan di Indonesia, diantaranya melalui penyempurnaan kurikulum dari kurikulum tingkat satuan Pendidikan (KTSP) menjadi kurikulum Nasional 2013. Menurut INPRES Nomor 1 tahun 2010, perubahan kurikulum dimaksudkan untuk percepatan pelaksanaan prioritas pembangunan sehingga dapat membentuk daya saing dan karakter bangsa.

Untuk dapat bersaing dengan bangsa-bangsa lain di dunia, keterampilan berpikir agar dapat memecahkan masalah disekitarnya menjadi suatu hal yang penting bagi bangsa Indonesia. Pendidikan merupakan salah satu wahana untuk mengembangkan kemampuan berpikir suatu bangsa. Sebagai lembaga yang melaksanakan pendidikan di Indonesia, sekolah turut serta bertanggungjawab dalam menyiapkan para siswa untuk mampu bersaing dalam era globalisasi dengan mengembangkan keterampilan berpikir siswa. Untuk itu, guru perlu melengkapi siswa dengan keterampilan untuk mencari, mengekstrak, menginterpretasi, mensintesis, dan mengevaluasi informasi. Guru seharusnya membekali diri siswa dengan sejumlah kompetensi, karena kompetensi merupakan salah satu kunci untuk memenangkan kompetisi. Kompetensi yang sangat diperlukan salah satunya adalah kompetensi ilmiah. Kompetensi ilmiah adalah prosedur, proses, dan metode yang digunakan para ilmuan ketika mengkonstruksi pengetahuan dan memecahkan masalah. Salah satu kompetensi ilmiah adalah kemampuan pemecahan masalah (problem solving competence). Kemampuan pemecahan masalah adalah usaha untuk mencari jalan keluar dari suatu kesulitan untuk mencapai suatu tujuan yang tidak begitu saja dengan segera dapat dicapai. Langkah-langkah dalam pemecahan masalah adalah memfokuskan masalah, menguraikan secara konsep fisika, merencanakan solusi, melaksanakan rencana pemecahan masalah, dan mengevaluasi jawaban (Heller P, et al, 1992).

Fisika merupakan mata pelajaran pokok yang diajarkan di Sekolah Menengah Atas (SMA) dan mata pelajaran yang diujikan dalam ujian nasional. Fisika merupakan salah satu bagian dari Ilmu Pengetahuan Alam (IPA). Pada tingkat SMA, pelajaran fisika menjadi satu mata pelajaran tersendiri. Hal ini bertujuan agar selain untuk memberikan bekal ilmu pengetahuan bagi siswa, pembelajaran fisika juga menjadi wahana untuk menumbuhkan kemampuan berpikir yang sangat berguna bagi siswa dalam memecahkan masalah di dalam kehidupan sehari-hari.

Fakta di

lapangan menunjukkan bahwa sebagian siswa tidak menyenangi pelajaran fisika dan sebagian besar siswa yang gagal dalam ujian nasional dikarenakan mata pelajaran fisika. Bryan \& Fennel (2009) menyebutkan hingga saat ini pembelajaran fisika masih lebih banyak menggunakan persamaan matematik sebagai pendekatan, sehingga siswa menganggap bahwa fisika merupakan mata pelajaran yang sulit dan sama dengan mata pelajaran matematika, akibatnya siswa 
mengalami kesulitan mengembangkan pemahaman hubungan antara matematika dan fisika. Hal ini berdampak pada kesulitan siswa dalam menyelesaikan soal-soal Fisika. Bahkan menurut Yusuf (2009), pembelajaran Fisika yang terlalu banyak menghabiskan waktu untuk masalah matematika melalui pemberian contoh dan latihan soal bisa menjebak siswa pada kebiasaan menghafal rumus-rumus fisika berbentuk persamaan matematika daripada memahami maknanya secara fisis dan soal-soal fisika yang berhubungan dengan pemahaman konsep-konsep dasar.

Untuk mengatasi kesulitan siswa dalam menyelesaikan soal-soal fisika diperlukan pembelajaran yang dapat meningkatkan kemampuan siswa dalam memecahkan masalah fisika, salah satunya adalah melalui pembelajaran dengan pendekatan multirepresentasi. Representasi adalah suatu konfigurasi (bentuk atau susunan) yang dapat menggambarkan, mewakili atau melambangkan sesuatu dalam banyak cara. Representasi merupakan sesuatu yang mewakili, menggambarkan, atau menyimbolkan objek dan/atau proses (Waldrip \& Prain, 2006). Mutirepresentasi adalah merepresentasi suatu konsep dalam banyak cara (Heuvelen \& Xueli, 2001). Jadi multirepresentasi adalah merepresentasi ulang konsep yang sama dengan format yang berbeda, termasuk verbal, gambar, grafik, dan matematik.

Penelitian Rosengrant, Etkina \& Heuvelen (2006) menyebutkan bahwa siswa yang menggunakan lebih dari satu representasi lebih tinggi kemampuan pemecahan masalahanya dibanding dengan siswa yang hanya menggunakan satu representasi. Selanjutnya, Kohl dan Finkelstein (2005) mengemukakan bahwa siswa yang mendapat pekerjaan rumah dengan empat bentuk representasi memiliki kemampuan pemecahan masalah yang lebih tinggi dibanding dengan siswa yang mendapat pekerjaan rumah hanya satu bentuk saja.

Penilaian merupakan salah satu bagian dari proses pembelajaran. Menurut Gredler (2011), salah satu penyebab kesulitan siswa dalam menyelesaikan soal adalah akibat lemahnya kemampuan siswa dalam mengidentifikasi soal yang diberikan. Siswa cenderung mengembangkan skema "soal kata" yang dipisahkan dari soal dunia nyata. Lebih lanjut diutarakan Gredler bahwa merepresentasikan masalah merupakan hal penting bagi keberhasilan siswa memecahkan masalah.

Hasil penelitian sebelumnya terhadap 73 orang siswa SMA di kota Pontianak menunjukkan bahwa $97 \%$ siswa menggunakan repre-sentasi persamaan matematika, $70 \%$ menggunakan representasi grafik, dan $30 \%$ menggunakan representasi gambar dalam menyelesaikan soal gerak lurus berubah beraturan. Siswa yang cenderung langsung menggunakan persamaan matematika dalam menyelesaikan soal tanpa memperhatikan makna fisis dari soal tersebut sehingga $65 \%$ siswa yang menjawab dengan persamaan matematika mengalami kesalahan. (Sirait J, et al, 2010).

Dari pemaparan di atas, maka dianggap penting melakukan kajian pengaruh pemberian soal dalam bentuk multirepresentasi bagi siswa 
dalam pelajaran Fisika terhadap keberhasilan siswa melakukan pemecahan masalah Fisika khususnya pada materi Dinamika Partikel di kelas XI SMA. Hasil penelitian ini digunakan untuk merancang pembelajaran fisika yang dapat meningkatkan kemampuan siswa dalam memecahkan masalah fisika.

\section{Metode}

Penelitian survey dilakukan untuk mendeskripsikan pengaruh pemberian soal multirepresentasi bagi siswa. Populasi teoritis dari penelitian ini adalah semua siswa SMA di Kalimantan Barat. Sedangkan populasi praktisnya adalah siswa untuk 4 (empat) daerah Kabupaten dan Kotamadya yang ada yaitu Kabupaten Ketapang, Kabupaten Landak, Kota Pontianak dan Kota administratif Singkawang. Pengambilan sampel dalam penelitian dilakukan dengan teknik purposive sampling dan mengambil secara utuh satu kelompok (naturally formed intact group). Sebanyak 235 siswa menjadi sampel dalam penelitian ini.

Alat pengumpul data yang digunakan adalah tes uraian pada materi Dinamika Partikel di kelas XI SMA. Soal uraian pada masingmasing sekolah diberikan dalam dua bentuk yaitu soal yang hanya dalam bentuk cerita verbal saja dan soal yang dilengkapi dengan gambar atau diagram. Analisis data dilakukan secara kuantitatif untuk mendeskripsikan kemampuan pemecahan masalah sampel berdasarkan bentuk soal yang diberikan.

\section{Hasil dan Pembahasan}

Analisis data hasil jawaban dilakukan dengan mengelompokkan siswa berdasarkan sekolah dan jenis tes soal yang dikerjakan. Hasil analisis data didekripsikan pada Tabel 1.

Tabel 1. Rekapitulasi hasil tes siswa

\begin{tabular}{|c|c|c|c|}
\hline Kelompok & \multirow{2}{*}{$\begin{array}{l}\text { Jumlah } \\
\text { Siswa }\end{array}$} & \multicolumn{2}{|c|}{$\begin{array}{l}\text { Skor Pemecahan } \\
\text { Masalah }\end{array}$} \\
\cline { 3 - 4 } & & $\begin{array}{l}\text { Tes } \\
\text { Verbal }\end{array}$ & $\begin{array}{l}\text { Tes } \\
\text { Bergambar }\end{array}$ \\
\hline I & 29 & 11,52 & \\
\hline II & 29 & & 11,07 \\
\hline III & 28 & 8,86 & \\
\hline IV & 27 & & 12,93 \\
\hline V & 36 & & 6,59 \\
\hline VI & 17 & 7,00 & \\
\hline VII & 34 & 12,19 & \\
\hline VIII & 35 & & 15,70 \\
\hline \multicolumn{2}{|c|}{ Rata-rata } & 9,89 & 11,57 \\
\hline
\end{tabular}

Tabel 1 menunjukkan hasil analisis kemampuan pemecahan masalah siswa dalam menyelesaikan soal Fisika yang diberikan. Terdapat dua macam soal yang diberikan pada siswa, yaitu yang soalnya hanya berupa soal teks cerita saja (verbal) dan soal yang diberikan representasi gambar disamping soal teks cerita. Analisis dilakukan untuk membandingkan dua kelompok siswa yang mengerjakan soal yang berbeda

Hasil analisis menunjukkan bahwa pada umumnya kelompok siswa yang soalnya diberi representasi gambar memberikan rerata skor yang lebih tinggi dibandingkan kelompok siswa pada sekolah yang sama namun soalnya hanya berupa teks cerita saja (verbal). Hal ini sesuai dengan tiga fungsi utama dari multirepresentasi, yaitu sebagai pelengkap, pembatas interpretasi, dan pembangunan pemahaman (Ainsworth, 1999). Fungsi multirepresentasi sebagai 
pelengkap digunakan untuk memberikan representasi yang berisi informasi pelengkap sehingga membantu melengkapi proses kognitif. Representasi gambar yang diberikan juga dapat membatasi kemungkinan kesalahan menginterpretasi soal dan rencana penyelesaiannya. Penyajian soal dengan menggunakan multirepresentasi dapat digunakan untuk mendorong siswa membangun pemahaman terhadap situasi secara mendalam. Penjelasan secara verbal melalui teks akan menjadi lebih mudah dipahami ketika dilengkapi gambar atau grafik yang relevan dengan informasi yang sedang dibicarakan.

Secara keseluruhan perbandingan dua kelompok siswa yang mengerjakan soal yang berbeda pada ke empat sekolah yang berbeda digambarkan pada diagram berikut:

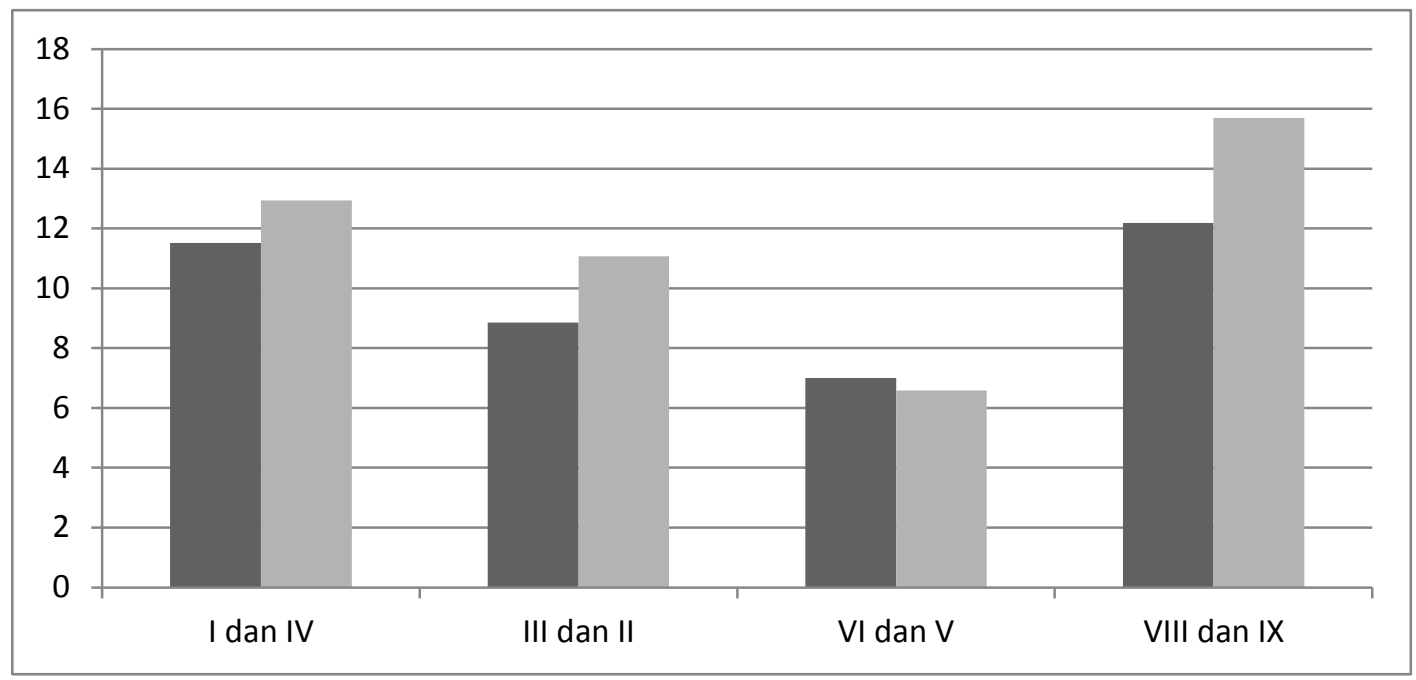

Gambar 2: Perbandingan rerata skor untuk kedua kelompok.

Diagram hasil pemecahan masalah siswa menunjukkan bahwa pada tiga sekolah, kelompok siswa yang diberikan soal yang berbeda menghasilkan skor yang berbeda juga. Kelompok siswa yang soalnya dilengkapi diagram atau gambar lebih tinggi rata-rata skornya dibandingkan dengan kelompok yang soalnya hanya dalam bentuk verbal saja.

\section{Simpulan}

Berdasarkan analisis data dan pembahasan dapat diambil kesimpulan bahwa siswa yang diberi soal dengan multirepresentasi lebih tinggi rata-rata skornya $(11,57)$ dibanding siswa yang hanya diberi soal dengan representasi verbal saja (9,89). Berdasarkan analisis dan pembahasan dapat disarankan implementasi pendekatan multirepresentasi dalam pelaksanaan penilaian dalam pembelajaran fisika.

\section{Daftar Pustaka}

Adadan E, Irving K E, Trundle K C. (2009). Impacts of multiplerepresentational instruction on high school students' conceptual understanding of 
the particulate nature of matter. International Journal of Science Education, 31:13, 1743-1775.

Ainsworth, S. E. (1999). The function of multiple representations. Computers and Education, 33, 131-152.

Borg, W. R \& Gall, M. D. (1983). Educational Research: An Introduction. Fourth Edition. New York: Longman Inc.

Bryan J A, Fennel B D. (2009). Wave modeling: a lesson illustrating the integration of mathematics, science and technology through multiple representations. Physics education. 44, (4), 403-410.

Gredler, Margaret E, (2011). Learning and Instruction, terjemahan Tri Wibowo,B.S Jakarta: Kencana, 2011.

Heuvelen, A.V and Xueli, Z. (2001). Multiple Reprsentation of Work-Energy Processes. American Journal of Physics. 69, (2), 184-194.

Kohl P B, Finkelstein N D. (2005). Students representational competence and selfassessment when solving physics problems. Physical

\section{Review Special Topics- Physics Education Research, 1, 010104-11.}

Rosengrant, D, Etkina, E \& Heuvelen, A.W. (2006). An Overview of Recent Research on Multiple Representation. PERC Proceedings.

Sirait J, Mursyid S, Haratua. (2010). Multirepresentasi Siswa SMA dalam Pemecahan Masalah Kinematika Gerak Lurus. Laporan Penelitian DIPA UNTAN.

Tim Puslitjaknov. (2008). Metode Penelitian Pengembangan. Pusat Penelitian Kebijakan dan Inovasi Pendidikan Badan Penelitian dan Pengembangan Departemen Pendidikan Nasional.

Waldrip, B and Prain, V . (2006). An Exploratory Study of Teacher's and Student's Use of Multi-Modal Representations of Concept in Primary Science. International Journal of Science Education. 28, (15), 1843-1866.

Yusuf. (2009). Deskripsi Kemampuan Siswa dalam Menyelesaikan Permasalahan Listrik Statis. Tesis SPS UPI: Tidak diterbitkan. 